\title{
ŻYCIE ZACZYNA SIĘ NA WYSYPISKU. O NIECHCIANYCH MIESZKAŃCACH MIAST
}

\author{
Life Begins at the Landfill. On Unwanted City Inhabitants
}

\begin{abstract}
The article deals with the problem of the ambivalent status of garbage in urban space. The author explores, based on the Diana Lelonek Center for Living Things project, how wastes co-create new ecosystems, undermining our understanding of the concepts of environment and wasteland, and resists the capitalist logic of overproduction and redundancy.
\end{abstract}

Keywords: wastes, city, wasteland, Center for Living Things, capitalism, environment, wilderness

Opanowują Ziemię na globalną skalę. W swoich nagromadzeniu zaczynają tworzyć własne terytoria, czego przykładem jest pływająca wyspa na Pacyfiku, pięć razy większa niż Polska. Śmieci. Ludzie próbują poddawać je nieustannej kontroli poprzez ich segregowanie, zbieranie i wywożenie. Miasta projektowane są tak, by trzymać odpady ${ }^{1}$ w ściśle określonych, odgrodzonych miejscach - w koszach, kontenerach, które ukrywają swoją zawartość, na wysypiskach znajdujących się na peryferiach. To śmieci odpowiedzialne są również za klasową stratyfikację miasta, podział na centrum (gdzie są niewidoczne) i peryferie - slumsy (w których współtworzą tkankę miejską). Jednakże odpady wymykają się tym ograniczeniom zarówno w makro-, jak i mikroskali. Odpady, choć postrzegane jako koniec łańcucha konsumpcji, rzeczy martwe i niepełniące już żadnej funkcji - żyją.

W niniejszym artykule chciałabym podjąć refleksję nad zaskakującym życiem rzeczy, które stają się śmieciami. Choć porzucone przez jeden łańcuch kapitalistycznej konsumpcji, włączane są w obieg alternatywny. Współtworzą nowy system miejskich ekosystemów. Punktem wyjścia moich rozważań będzie projekt Diany Lelonek pod nazwą Instytut dla żywych rzeczy, a towarzyszyć będzie mi pytanie o to, czy

1 W tym artykule terminy „śmieć” oraz „odpad” traktuję synonimiczne i używam ich zamiennie. 
śmieci mogą stać się ważne w rozwoju i powstawaniu nowych ekosystemów. Odpady będę traktować zgodnie z biosemiotyczną perspektywą, jako znak czegoś żywego, co nie tylko pozostawia ślad dawnej obecności (jako rzecz), ale także rozpoczyna nową egzystencję. Niezwykle istotną perspektywę stanowić będzie dla mnie również filozoficzna refleksja nad rzeczami, zarówno z obszaru ontologii zorientowanej na obiekty (object-oriented ontology), jak i nowego materializmu proponowanego przez Jane Bennett. Uważam, że pozwoli mi to ukazać sposób, w jaki śmieci wchodzą z ludźmi w relację i w tych relacjach się ukazują, ale również będę mogła się zastanowić nad twórczym potencjałem odpadów.

\section{Gdzie kończy się rzecz, a zaczyna śmieć}

Jak zwraca uwagę Zygmunt Bauman, pojęcie śmiecia jest wytworem ery nowoczesnej. To wtedy nastąpiło przejście od przedustawnego porządku rzeczy, w którym człowiek miał strzec tego, co już jest, do planowania pożądanego porządku rzeczy i jego wdrażania ${ }^{2}$. Oczywiście można powiedzieć, że wraz z rozwojem cywilizacji rosła liczba produkcji śmieci, ale to dopiero modernizacja doprowadziła do ich wytwarzania na masową skalę. Radzenie sobie z odpadami, wcześniej oparte na ciągłym wykorzystywaniu i przetwarzaniu tego, co straciło swoją dotychczasową funkcję, zmieniło się w gest brutalnego odrzucenia: ,(...) pozbywamy się śmieci w najradykalniejszy i najskuteczniejszy sposób: nie patrzymy na nie, sprawiając, że stają się niewidzialne, i nie myślimy o nich, sprawiając, że stają się nie do pomyślenia"3. Jak zwraca uwagę Marek Krajewski, śmieci powstają wskutek wytwarzania porządku, ich status zaczął zależeć od nadawania im ,śmieciowej” etykietki. Stały się więc relacyjne i relatywne 4 . Tym samym wyrzucanie to gest samookreślania i tworzenia ludzkiej tożsamości ${ }^{5}$. Ujawnia się tutaj głęboko performatywny charakter odpadu - jego status opiera się na geście odrzucenia, uczynienia niewidocznym. Staje się czymś pozornie nieszkodliwym i niematerialnym (wręcz oddzielonym od swej fizyczności) ${ }^{6}$ - usunięty na granice rzeczywistości przestaje na nią oddziaływać. Uważam jednak, że jest to bardziej stan postulatywny niż rzeczywisty. Rzeczy, stając się śmieciami, nie przestają oddziaływać na rzeczywistość, a czasami zaczynają mieć na nią nawet większy wpływ. Wchodzą w interakcję ze środowiskiem, sprawiając, że pod ich wpływem ziemia na wysypiskach porusza się, a czasami eksploduje, ześlizguje się bądź zapada. Posiadają specyficzną moc-rzeczy (thing-power), która sprawia jak pisze Bennett - że śmieci ujawniają zdolność do działania, wpływania w różnej

Z. Bauman, O przemijaniu trwania, w: K. Kulikowska, C. Obracht-Prondzyński (red.), Śmieć w kulturze, Wydawnictwo Naukowe Katedra, Gdańsk 2015, s. 38.

Z. Bauman, Życie na przemiat, Wydawnictwo Literackie, Kraków 2005, s. 47.

M. Krajewski, Śmieć w sztuce. Sztuka jako śmieć, „Zeszyty Artystyczne” 2004, nr 13, s. 2.

Ibidem.

6 Na temat specyficznej ontologii śmieci zob. G. Kennedy, An Ontology of Trash: The Disposable and Its Problematic Nature, State University of New York Press, New York 2007. 
skali na rzeczywistośćc ${ }^{7}$ Oddziałują na inne obiekty, ludzi, nie-ludzi, materię - wywołują efekt w świecie. Są witalne w tym sensie, że: ,(...) nie tylko utrudniają lub blokują ludzkie zamiary, ale także działają jako quasi-agenci lub siły o własnych trajektoriach, skłonnościach lub tendencjach"». Ścieki zmieniają barwę rzek i ich ekosystem. W żołądkach ryb odnajdujemy plastik. Śmieci stają się współcześnie częścią ludzkiego ciała, w którym elementy plastiku łączą się z wewnętrznymi organami, tworząc dziwne hybrydy i znosząc podział między zewnętrzem, w którym ciało istnieje, a wnętrzem pozwalającym na jego funkcjonowanie. Odpady wchodzą w złożoną sieć relacji z innymi nie-ludzkimi i ludzkimi materiami, ale również tworzą nowe połączenia ze światem.

Pokazuje to, że choć w warstwie symbolicznej odpad to coś, co już nie przynależy do świata, to ma on jednak istotny wpływ na materialną rzeczywistość i jest impulsem do jej transformacji. Nie jest końcem życia a jego kontynuacją. Jednakże śmieć również w swojej warstwie znakowej nie jest czymś stałym. Dzięki semantycznemu bogactwu dość łatwo może wrócić do obiegu rzeczy i być ponownie wykorzystany. Przez gest ponownego przywłaszczania zostaje on włączony w horyzont rzeczy ważnych a nawet drogocennych - taki status uzyskało wiele ,śmieci starożytności”, stając się obiektami muzealnymi, podziwianymi i podlegającymi trosce. Śmieć jest zatem czymś płynnym i nieokreślonym na wszystkich swoich poziomach istnienia: „(...) coś jest śmieciem nie ze względu na jego właściwości, lecz ze względu na przyjęty porządek rzeczy odnotowany w kulturowo kształtowanej świadomości"".

Współcześnie, w dobie antropocenu ${ }^{10}$ i przerażającej wręcz nadprodukcji odpadów, status śmieci staje się jeszcze bardziej złożony oraz zyskuje głębszy wymiar polityczny. Plastik i cement tworzą nową warstwę geologiczną, zmieniając strukturę Ziemi. Jesteśmy jednak świadkami nowego rodzaju kolonializmu, w którym śmieci Globalnej Północy przejmują Globalne Południe. Sprawia to wręcz, że cała rzeczywistość staje się śmieciowa, oparta na odpadkach. Wszystko (od rzeczy, poprzez emocje, ludzkie i nie-ludzkie byty) staje się zbędne, nietrwałe i w każdej chwili mogące znaleźć się na jakimś wysypisku. Śmieci można traktować jak Mortonowski hiperobiekt. Oddziałuje nie tylko przez samą obezwładniającą ilość, lecz także jako istotna siła zmian geologicznych i ekologicznych. Odpady, przez ich globalne oddziaływanie, możemy współcześnie rozpoznać jedynie na poziomie lokalnym w ich

J. Bennett, Vibrant Matter: A Political Ecology of Things, Duke University Press, Durham-London 2010, s. 6.

$8 \quad$ Ibidem, s. 8.

$9 \quad$ Z. Bauman, O przemijaniu..., s. 41.

10 Oczywiście degradacja środowiska nie jest jedynie zjawiskiem współczesnym, można wręcz stwierdzić, że od początku istnienia człowiek eksploatował swoje otoczenie. Po dziś dzień trwają debaty nad wyznaczeniem początku epoki antropocenu, choć naukowcy skłaniają się, by były to lata 50. XX w. i wzmożone testy z bronią nuklearną. Ilość śmieci współcześnie osiągnęła taki poziom, że kilkakrotnie przekracza możliwości składowania ich na Ziemi. 
pojedynczych przejawach, już jednak wskazanie całościowego obrazu staje się niemożliwe (również ze względu na ich niewyobrażalną ilość):

Są lepkie, co oznacza, że ,przyklejają się” do istot z nimi powiązanymi. Są nielokalne - innymi słowy, „lokalna manifestacja” hiperobiektu nie jest bezpośrednio tym hiperobiektem. Obejmują one całkowicie odmienne czasowości niż te na ludzką skalę, do których jesteśmy przyzwyczajeni. (...) Hiperobiekty zajmują wielowymiarową przestrzeń, przez co mogą być niewidoczne dla ludzi przez długi czas. Hiperobiekty nie są funkcją naszej wiedzy: są relacją pomiędzy robakami, jedzeniem i promieniami ultrafioletowymi, a także ludźmi ${ }^{11}$.

Śmieci możemy dostrzec wtedy, kiedy zadecydujemy, że dany przedmiot stał się już nieużyteczny. Tym samym są one w pewien sposób skryte - nie dostrzeżemy śmiecia jako takiego, powstaje on dopiero w relacji z nami, nadającymi mu status odpadu, oraz innymi obiektami, nadal pozostającymi w sferze rzeczy ${ }^{12}$. Śmieci istnieją w relacji: z ludźmi, ponieważ to oni decydują, co staje się odpadem; z nie-ludźmi, ponieważ wkraczają w ich rzeczywistość, transformując ją; i w relacjach między sobą, wzajemnie się przekształcając i współ-żyjąc. Odpady są hiperobiektami również dlatego, że zmuszają nas do zmiany, wpływają na idee tego, co znaczy życie, Ziemia, środowisko, ale również społeczeństwo ${ }^{13}$. Relacja z odpadami jest w tym sensie estetyczna, że widzimy ich przejawy, reprezentacje, ale nie dostrzeżemy samych śmieci jako jednej, spójnej całości ${ }^{14}$. Śmieci bardzo często istnieją dłużej niż ich wytwórcy. Plastik nigdy nie ulegnie rozpadowi, jedynie stopniowemu zmniejszaniu na coraz to mniejsze cząsteczki ${ }^{15}$, tworząc pył na zawsze osiadający w ziemskiej rzeczywistości ${ }^{16}$. Odpady tworzą również nową czasowość, wykraczającą poza ludzkie rozumienie temporalności - przejawy konsumpcyjnej działalności będą przekraczać setki tysięcy lat, paradoksalnie zaprzeczając pożądanej przez kapitalizm krótkotrwałości obiektów.

\section{Niepożądani mieszkańcy miast}

Nowoczesne miasta budowane są na zasadzie nieprzepuszczalności i pewnej sterylności. Ziemia w nich przykrywana jest przez asfalt, kamienie i cegły. Małe wyspy

11 T. Morton, Hyperobjects: Philosophy and Ecology after the End of the World, University of Minnesota Press, Minneapolis-London 2013, s. 10.

12 T. Morton, Realist Magic: Objects, Ontology, Causality, Open Humanities Press, Ann Arbor 2013, s. 57.

13 T. Morton, Hyperobjects..., s. 19.

14 T. Morton, Realist Magic..., s. 57.

15 H. Davis, Life \& Death in the Anthropocene: A Short History of Plastic, w: H. Davis, E. Turpin (red.), Art in Anthropocene: Encounters among Aesthetics, Politics, Environments and Epistemologies, Open Humanities Press, London 2015, s. 350.

16 A. Galland, Waste \& Opportunity: U.S. Beverage Container Recycling Scorecard and Report, As You Sow, San Francisco, CA 2008, s. 17. 
zieleni są poddawane kontroli i utrzymywane w narzuconych granicach, często wręcz ogradzane, a tylko określone byty (bardzo często jedynie ludzkie) mogą w nich przebywać. Takie miasta nastawione są na silne odrzucanie tego, co nie mieści się w ich ramach, znajduje się „nie na miejscu”" z których zostały zbudowane. W związku z tym konieczne było stworzenie złożonej sieci pozbywania się tego, co niechciane - ukrytej kanalizacji, zsypów i zamkniętych koszy na śmieci aż po istniejące na granicach miast ogrodzone i zamknięte składowiska śmieci. Jednocześnie zarządzanie odpadami staje się narzędziem określania statusu społecznego i klasowego mieszkańców miast - na tych, którzy usuwają, oraz tych, którzy w wyniku społecznych nierówności żyją ze śmieciami i włączają je w swoją rzeczywistość. Tym samym miasto doprowadza do rozdzielenia odpadu, jego alienacji, od ciała, które go wytworzyło. Dlatego też częściej mówi się o śmiechach, odpadach, niż używa się ich liczby pojedynczej:

Wmieszane w odpady innych ludzi, odrzuty tracą indeksowe powiązanie z bytem, który je wytworzył, stają się anonimowe i zyskują abstrakcyjny, ogólny charakter. Mówimy o ,śmieciach” i ,odpadach” jako rzeczownikach w liczbie mnogiej, jako rodzaju ogólnej substancji, ale dzieje się tak tylko dlatego, że istnieją systemy do ich składowania w ten sposób ${ }^{18}$.

Miasta są odpowiedzialne za nowy, masowy status odrzutów, które są raczej odkładane na bok, niż ponownie przetwarzane jak to działo się np. na wsiach bądź przed rozwojem nowoczesnych metropolii. Gest ponownego wykorzystania odpadów nie zniknął jednak całkowicie, a zyskał nowy wymiar ekonomiczny oraz klasowy. Tak jak na wsiach wykorzystywano własne odpady, tak ludzie w slumsach przetwarzają odpady, które mogą pochodzić z zupełnie innego kontynentu. W takich miejscach jak Dharavi (dzielnica Bombaju) tworzy się ze śmieci domy, narzędzia, środki przetrwania. Praca ludzi mieszkających w slumsach często związana jest z segregowaniem, oddzielaniem i przetwarzaniem odpadów. Tym samym można powiedzieć, że to, co niewidoczne dla jednych, staje się centrum egzystencji drugich. Usuwanie śmieci ukazuje nie tylko poziom urbanistycznego rozwoju danej przestrzeni, ale i prawa dystrybucji wyrażane w strukturach miasta. Można określić granice i centrum danej metropolii na zasadzie obecności bądź nieobecności odpadków.

Miasto doprowadziło również do powstania nowej kategorii przestrzeni istniejącej w jego obrębie - nieużytku (wasteland). Oryginalnie termin ten używany był do określania przestrzeni, które znajdowały się poza sferą cywilizacji (kultury), współcześnie często stosuje się go w kontekście obszarów zniszczonych przez przemysł, porzuconych przez wojsko bądź zanieczyszczonych przez różnego rodzaju odpady. Spowodowało to, że ziemie jałowe jednocześnie zaczęły być przestrzeniami istnie-

17 M. Douglas, Czystość i zmaza, przeł. M. Bucholc, Państwowy Instytut Wydawniczy, Warszawa 2007, s. 46.

18 J.O. Reno, Toward a New Theory of Waste: From 'Matter out of Place' to Signs of Life, „Theory, Culture \& Society" 2014, vol. 31 (6), s. 25. 
jącymi poza kulturą, ale również stały się jej produktem. Jak wskazuje Vittoria Di Palma w swojej książce Wasteland: A History:

Nieużytek jest kulturowym konstruktem, tworem wyobraźni, kategorią stosowaną do krajobrazów, a nie ich nieodłączną cechą. Jako konstrukcja spełnia pewne potrzeby kulturowe, społeczne i psychologiczne, a przede wszystkim zapewnia rolę na rzecz krajobrazu życzliwego, łatwego w obsłudze lub przyjemnego. Pustkowie są zatem instrumentalne - a nawet fundamentalne $-\mathrm{w}$ formułowaniu ideału krajobrazu ${ }^{19}$.

Przestrzenie odrzucone, zaśmiecone stają się zatem pewnego rodzaju negatywnym odniesieniem dla idealnego, uporządkowanego i czystego krajobrazu. Umieszczanie składowisk odpadów na granicach miasta uwidacznia ten podział - idealna metropolia to taka, która rzeczy niepotrzebne usunęła poza swoją ramę, nie tylko wizualną, ale również poznawczą. W samej tkance miasta podział ten jest wyraźny rzeczy, dobra na sprzedaż są widoczne i dostępne, odpady są ukrywane ${ }^{20}$.

Same wysypiska śmieci nie są przestrzeniami jasno zdefiniowanymi. Istnieje pojęciowa różnica między terminami „wysypisko śmieci” i ,składowisko”. Wysypiskami nazywa się miejsca nielegalnej wywózki śmieci, mogą one znajdować się wszędzie. Legalne zaś miejskie obszary wyrzucania odpadów nazywane są składowiskami - punktami komunalnego zrzutu odpadów ${ }^{21}$, jak na przykład Wola Ducka pod Otwockiem, obszary pod Mławą oraz w Miączyniu, gdzie składowane są odpady z Warszawy. Składowiska to niemalże antonim nieużytku - nie są one przestrzeniami pustymi, opuszczonymi, a wręcz przepełnionymi rzeczami i procesami zachodzącymi pomiędzy nimi. Stanowią zaprzeczenie ich postulatywnej niewidzialności - góry odpadów dominują w krajobrazie, w którym się znajdują, a ich obecność odczuwana jest zmysłowo (nie tylko przez wzrok, ale i przez węch):

Śmiecie także nie „znikają”, jak się potocznie sądzi, i nie da się o nich „zapomnieć”, czego byśmy bardzo chcieli. Śmiecie są z nami cały czas. Tak, śmiecie są „wyrzucone”, ale nie „opuszczone”, i wcale nie są „czcze”, czyli ,jałowe”. Są żywiołem niezdeterminowanym zarówno w sensie materialnym - na wysypisku wszystko zmieszane jest ze wszystkim, jak i w sensie językowej ambiwalencji - nie ma z góry ustalonej klasy śmieci, śmieciem może stać się wszystko, tzn. wszystko może być nazwane śmieciem² ${ }^{22}$.

Chociaż wywożone poza granice miast, są ciągle obecne jako pewne widma (również jeśli pomyślimy o ekologicznych konsekwencjach składowania śmieci) idealnego ludzkiego świata. Obnażają one z jednej strony ludzki system nadprodukcji, oparty na odgórnej zbędności wytwarzanych rzeczy, a z drugiej pokazują uporczywe

19 V. Di Palma, Wasteland: A History, Yale University Press, New Haven-London 2014, s. 9.

20 Oczywiście jest to stan bardziej postulatywny niż rzeczywisty, czego przykładem są takie miasta, jak Paryż bądź Nowy Jork.

21 W. Pessel, Antropologia nieczystości. Studia z kultury sanitarnej Warszawy, Wydawnictwo Trio, Warszawa 2009, s. 443.

22 J. Leociak, Góry śmieci otulały wata smrodu wszystko, co żyło. (Śmieci w getcie warszawskim w perspektywie środowiskowej historii Zagłady), „Teksty Drugie” 2017, nr 2, s. 113. 
trwanie przedmiotów wbrew ludzkim założeniom. Nazwanie czegoś odpadem albo gest wyrzucenia nie powodują, że dany obiekt znika. Istnieje jedynie poza ludzką logiką użyteczności, potrzeb i pożądania.

Nielegalne, dzikie wysypiska śmieci, które można dostrzec w przyblokowych laskach, na trawnikach, ruinach budynków sprawiają, że śmieci są widoczne i sprawcze, ingerują w tkankę miasta ${ }^{23}$. Przestrzenie te pokazują, jak obiekty wymykają się ludzkiemu pożądaniu ładu i czystości. Zajmują obszary, które nie były dla nich przeznaczone, tworzą nowe sieci relacji i zjawisk, które inaczej nie mogłyby zaistnieć. W tym też leży ich twórczy potencjał ${ }^{24}$, który często był wykorzystywany w sztuce nowoczesnej, ale obecny jest również współcześnie w twórczości artystów.

\section{Sztuka ze śmietnika}

Śmieci wkroczyły do sztuki nowoczesnej wraz z pojawieniem się ruchów awangardowych. Pierwszym krokiem ku temu były działania futurystów i ich zainteresowanie życiem miasta, maszyn, przemysłu. Oczywiście najbardziej wyrazistym momentem, kiedy śmieci „wkroczyły na salony”, były obiekty tworzone przez dadaistów, a zwłaszcza słynna Fontanna Marcela Duchampa zaprezentowana w 1917 roku. Wykraczanie poza klasyczne ramy sztuki zachodziło również na poziomie samych technik, a pojawienie się kolażu i asamblażu umożliwiało coraz śmielsze włączanie w strukturę dzieł sztuki obiektów odrzuconych. Śmieci zyskały na jeszcze większym znaczeniu w latach sześćdziesiątych i siedemdziesiątych XX wieku wraz z nurtem arte povera i używaniem materiałów (takich jak filc), które dotychczas nie były uznawane za materiał sztuki. Wzrost zainteresowania odpadami u artystów nastąpił w związku z coraz większą produkcją śmieci, które nie tylko stały się materialnym obiektem, ale też zaczęły stanowić metaforę społeczeństwa żyjącego i produkującego śmieci (na poziomie materialnym i symbolicznym). Koniec XX wieku wprowadził do nurtu sztuki takie zjawiska, jak recykling i upcycling, których obecność wiązała się również z rosnącym zainteresowaniem artystów kwestiami dewastacji środowiskowej Ziemi i rosnącego zanieczyszczenia ${ }^{25}$. Podsumowując - śmieci w sztuce

23 Przykładem takiej przestrzeni jest mały lasek na Siekierkach, niedaleko miejsca, gdzie mieszkam. Ludzie wyrzucają tam śmieci, wyprowadzają psy, ale również tworzą z odpadów przestrzenie do wspólnego spędzania czasu. Śmieci są wręcz nad-widoczne, ale zaczynają integralnie współtworzyć tę przestrzeń.

24 Leży on również w geście otwierania granic ludzkiego ciała na otaczają go rzeczywistość (mikroplastik, azbest, radioaktywność), znosząc - jak wskazuje Timothy Morton - klasyczną różnice pomiędzy człowieczeństwem a naturą. Zob. T. Morton, Ecology without Nature: Rethinking Environmental Aesthetics, Harvard University Press, Cambridge, MA-London 2007, s. 108.

25 Dobrą syntezę historycznych relacjami pomiędzy sztuką a śmieciami stanowi artykuł Pawła Możdżyńskiego. Zob. idem, Prawdy odpadu. Najważniejsze konteksty i znaczenia zwiazane ze śmieciami w sztukach wizualnych i dizajnie XX $i$ XX wieku, w: K. Kulikowska, C. Obracht-Prondzyński (red.), Śmieć w kulturze, s. 421-444. 
służyły głownie jako element krytyki (samej sztuki bądź społeczeństwa), stanowiły tworzywo lub poddawane były artystycznemu recyklingowi ${ }^{26}$.

Apogeum tego procesu można obserwować współcześnie wraz ze wzrastającą popularnością terminu antropocen i roli, jaką odgrywa on w sztuce współczesnej ${ }^{27}$. Artyści zaczęli ukazywać paradoksalne piękno śmieci. Paradoks ten uwidocznił rosnącą potrzebę stworzenia nowej estetyki - zaangażowanej, niosącej społeczną zmianę w czasach globalnej destrukcji. Przykładem tego są prace takich artystów, jak Agnieszka Kurant (Postfordyt, 2019), bądź fotografie Edwarda Burtynsky'ego (Plastics Recycling, Nairobi, Kenya, 2016). W erze, w której środowisko i jego stan stały się jedną z najważniejszych debat społecznych, zmienia się również pojęcie samego piękna, które zaczęło uzyskiwać bardzo niepokojący i ambiwalentny status. Staje się ono czymś trochę dziwnym, odrzucającym, ale również fascynującym ${ }^{28}$. Związane $\mathrm{z}$ tym trudności w definiowaniu danych zjawisk jako piękne umożliwia dostrzeżenie rzeczy, które dotąd były pomijane, a mogą nie tylko stanowić ważny element estetyczny, ale też odgrywać istotną rolę w zmieniającym się świecie antropocenu. Codzienność, a w tym wypadku powszechność, śmieci oddziałuje przede wszystkim w wymiarze estetycznym ${ }^{29}$.

Przykładem, który bardzo dobrze uwidacznia złożoność relacji pomiędzy ludźmi a śmieciami, ich miejscem w mieście oraz środowiskowym potencjale, jakie ze sobą niosą, jest projekt Diany Lelonek Instytut dla żywych rzeczy tworzony od 2016 roku. Jest to parainstytucja naukowa założona w celu badania, gromadzenia i popularyzacji wiedzy na temat nowych form - jak nazywa je artystka - natury humanoicznej ${ }^{30}$. Obiekty są zbierane przede wszystkim na terenach Polski, na nielegalnych wysypiskach odpadów. Kolekcja składa się ze znalezionych na nielegalnych, dzikich wysypiskach śmieci przedmiotów pokrytych mchem, porostami i roślinami, zestawu fotografii oraz dokumentacji badawczej. Wszystkie eksponaty zgromadzone w zbiorach instytutu to porzucone przedmioty, zużyte i niepotrzebne towary - odpady ludzkiej nadprodukcji, które stały się środowiskiem naturalnym dla wielu żywych organizmów. Wskazują również na transgresyjny potencjał nielegalnych wysypisk jako obszarów, gdzie zachodzą procesy hybrydyzacji przedmiotów z roślinami. Te hybrydy roślin i sztucznych obiektów są trudne do sklasyfikowania, ponieważ są jednocześnie ożywione oraz nieożywione. Niemożność ich jednoznacznego skategoryzowania wymyka się też ustalonym reżimom produkcji wiedzy, wyrażanej w nazywaniu i porządkowaniu nie-ludzkiego świata, by poddać go kontroli. Pokazuje to, jak śmieci oddziałują również na poziomie epistemologicznym, ponieważ wskazują na

\footnotetext{
M. Krajewski, Śmieć w sztuce..., s. 11.

Por. H. Davis, E. Turpin (red.), Art in Anthropocene...

28 T. Morton, Dark Ecology: For a Logic of Future Coexistence, Columbia University Press, New York 2016, s. 144.

29 T. Morton, Realist Magic..., s. 20.

30 D. Lelonek, Center for Living Things, http://dianalelonek.com/portfolio/center-for-the-living-things/ (dostęp: 7.11.2019).
} 
nieprzystawalność kategorii definiujących ludzkie relacje ze środowiskiem i wprowadzają w nie chaos. Diana Lelonek w swoim projekcie eksploruje również złożone relacje człowieka z innymi gatunkami, próbując stworzyć niehierarchiczny świat oparty na współzależności pomiędzy ludźmi a nie-ludzkimi bytami. Znalezione i włączone przez artystkę do kolekcji obiekty są hybrydami tego, co odrzucamy - śmieci, oraz tego, co chcemy chronić - środowiska. Lelonek pokazuje, że przestrzenie, które uznajemy za nieużytki, miejsca skażone i zaśmiecone, mają potencjał tworzenia nowych form środowiskowych, zaprzeczając tym samym wpisywanym w nie kategoriom jałowości i nieużyteczności. Porzucone śmieci dosłownie zaczynają współtworzyć miejsca zieleni, wrastać w nie, stając się istotną częścią miejskich ekosystemów.

Tajemniczy i nieokreślony status zebranych obiektów widoczny jest już w samym haśle towarzyszącym projektowi Lelonek: „Rzeczy nie są tym, czym były” Z jednej strony wskazuje na niejednoznaczność wyników ludzkiej produkcji i ciągłą zmianę ontologicznego statusu rzeczy. Z drugiej strony nie wyjaśnia jednak, czym rzeczy są teraz - odpadami, dziełami sztuki, nowymi ekosystemami (a może wszystkim w tym samym czasie)? Motto uzmysławia, w jaki sposób zebrane obiekty są nieredukowalnie i odporne na pełne zrozumienie, wymykające się wszelkim kategoryzacjom. Dzięki temu śmieci-rośliny stają się otwarte nie tylko na interpretację, ale na różne, zmieniające się sposoby interakcji z nimi. Śmieci, będąc produktem ludzkiej działalności, są bardzo blisko nas, ale są również bardzo obce, niesamowite (we Freudowskim rozumieniu nie-samowitości). Instytut dla żywych rzeczy ze swoimi obiektami i procesami można włączyć do szerokiej kategorii hiperobiektu, w której również śmieci się znajdują. Nie są to tylko kolekcje, systemy lub zespoły różnych przedmiotów - nie można ich doświadczyć bezpośrednio, ale jedynie za pośrednictwem innych podmiotów w jakiejś wspólnej przestrzeni zmysłowej, przestrzeni sztuki, przestrzeni wystawienniczej lub przestrzeni mentalnej naszego postrzegania odpadów i środowiska. Ważną cechą Instytutu dla żywych rzeczy jest jego szczególna przyczynowość (w jaki sposób te byty manifestują się dla innych bytów), która opiera się na relacjach estetycznych. Nie są one już obiektami wiedzy (obliczalnymi i przewidywalnymi), lecz stają się samodzielnymi istotami. Wymykają się ustalonym wzorcom percepcji i reprezentacji takich zjawisk jak śmieci lub bogate ekosystemy. Projekt ukazuje sieć relacji, w jakich śmieci istnieją z przestrzeniami miejskimi, i ewokuje dwie niezwykle istotne kwestie: kapitalizmu i statusu przyrody w miastach. Przez pracę Lelonek chciałabym pokazać, jak śmieci i odpady działają przeciw logice hiperkapitalizmu oraz pokazują, że należy się troszczyć również o to, co początkowo zostało porzucone ${ }^{32}$.

\section{Ibidem.}

32 Pomijam tutaj pytanie o włączanie śmieci w rynek obiegu sztuki, ponieważ temat ten - choć istotny - zasługiwałby na osobny artykuł, a nie na grożącą uproszczeniem krótką refleksję. Prace Lelonek traktuję jako pewną refleksję nad potencjalnością hybrydowych form, ich status dzieł sztuki jest dla mojej refleksji drugorzędny. 


\section{Antykapitalistyczny opór śmieci}

Odczuwane współcześnie poczucie nadmiaru i przebodźcowania jest wytworem kapitalizmu. Nadprodukcja przedmiotów, oparta na tworzonej iluzji konieczności ciągłego zaspokajania nowych potrzeb, doprowadziła to zalewu rzeczywistości przez śmieci. Wywołało to kryzys gospodarki odpadami, kiedy obszary służące dotychczas za ogólnoświatowy śmietnik (oceany, kraje Globalnego Południa itd.) stały się przepełnione odpadami. W miastach, by poradzić sobie ze śmieciami w kapitalistycznym duchu, stosuje się metodę inkorporacji:

Ponieważ odpady zdradzają „,ciemne i wstydliwe tajemnice wszelkiej produkcji”, z konieczności muszą zostać zneutralizowane wewnątrz systemu. Jako elementy heterogeniczne i zagrażające koherencji systemu, zostają one więc poddane procedurom bezpiecznego włączenia w struktury ustalonego porządku ${ }^{33}$.

W logice tej kwitnący, choć w rzeczywistości mało wydajny, jest biznes zajmujący się recyklingiem. Odpady zostają przekształcane w materiał na kolejne rzeczy, które w krótkim czasie ponownie staną się śmieciami, by nieustannie krążyć w tym toksycznym obiegu materii. Wyraża to głębokie przeświadczenie, że w najbardziej wydajnej gospodarce nie ma miejsca na marnotrawstwo, a każda substancja ma potencjał generowania zysku.

Projekt Lelonek idzie niejako pod prąd tej logiki nieprzerwanego zysku. Celem nie jest wytworzenie nowych przedmiotów, a propozycja nowego sposobu interakcji ze środowiskiem - przez relacje estetyczne, widzenie przedmiotów tak, jak nam się ukazują. Instytut dla żywych rzeczy ma na celu opisanie mechanizmów pojawiających się w sferze odrzucenia i bezużyteczności. W tym obszarze produkty nie są już narzędziami używanymi przez ludzi, choć nadal - pomimo ich ludzkiego odrzucenia - uczestniczą w prawie każdym procesie zachodzącym w biosferze. Nie możemy definitywnie oddzielić procesów gospodarczych lub społecznych od tak zwanego procesu naturalnego. System śmieci-roślin opiera się na cyrkulacji symbiotycznej w przeciwieństwie do kapitalizmu, który jest oparty na liniowym przymusie postępu. Obiekty znajdujące się w kolekcji instytutu pokazują inny sposób ponownego użycia śmierci, oparty na symbiozie z innymi nie-ludzkimi organizmami, przeciwny do wchłoniętej przez kapitalizm idei recyklingu. Projekt Lelonek ma na celu skupienie uwagi na procesach zachodzących w sferach kapitalistycznego odrzucenia, odnosząc je i porównując z opracowanymi przez człowieka procesami oraz kapitalistyczną nadprodukcją. W tym samym czasie artystka szuka powiązań i możliwych alternatyw dla obecnej sytuacji. Śmieci nie są przetwarzane, by stworzyć nowe obiekty, ale tworzą całe nowe systemy życia i sieci relacji ze środowiskiem. Nie jest to obieg materii w jego ekonomicznym rozumieniu, a raczej przemiana oparta na cykliczności

33 A. Chomik-Krzykawska, Między odrzuceniem a przyswojeniem. Odpad udomowiony, „Kultura Współczesna” 2007, nr 4 (54), s. 34. 
przynależnej środowisku - wzajemnemu wchłanianiu się i zlewaniu z sobą, by umożliwiać życie w ogóle. Ujawnia się tutaj nowy potencjał śmieci, nie tylko jako przedmiotów czekających na ponowne odkrycie. Ich moc-rzeczy, posługując się sformułowaniem Bennett, opiera się na możliwości tworzenia nowego, hybrydowego świata.

Rozpoczęty ruch przeciw kapitalizmowi w projekcie Lelonek odbywa się również na poziomie samej relacji człowieka ze środowiskiem. Jak wskazuje Morton, środowisko zostało wchłonięte przez raczkujący jeszcze wtedy kapitalizm w XIX wieku, głównie w epoce romantyzmu ${ }^{34}$. Dzikość stała się wtedy rezerwuarem niewykorzystanego kapitału i zaczęła podlegać podobnej estetyzacji jak produkty w sklepowej witrynie. Przyroda zawsze znajdowała się tam, dalej - za szybą, jak pewien produkt, którego możemy jedynie pożądać. Obiekty kolekcjonowane przez Lelonek podważają tę zależność pomiędzy dzikością-przedmiotem-kapitalizmem. Ekosystemy powstają na śmieciach, odrzutach tego, czego system nie był w stanie w siebie wchłonąć. Rosną według własnej logiki, nie są kontrolowane ani tworzone przez ludzi. Tym samym można byłoby uznać je za nowe, alternatywne dzikie środowiska. Jednakże powstają one na syntetycznych wytworach człowieka, nie można więc stwierdzić, czy są sztuczne, czy naturalne. Jako takie tworzą przestrzenie nowej dzikości w obszarach miejskich, nielegalnych wysypiskach śmieci, które jednak zaburzają wcześniej istniejące ekosystemy (zaśmiecone lasy itd.). Porządek i ład zostaje zmieniony również w sferze poznawczej. Dzięki temu splątaniu różnych rejestrów śmieci-rośliny nie mogą same w sobie zostać wchłonięte w kapitalistyczną logikę nieustannego przetwarzania i wytwarzani dóbr. Nie są już śmieciami, nie staną się nowymi przedmiotami, są pół-roślinami. Ich hybrydyczność stawia opór rzeczywistości opartej na jasnych podziałach i klasyfikacjach. Nie można ich przetworzyć, zawłaszczyć, można jedynie - podobnie jak robi to Lelonek - obserwować przemiany dokonujące się na tych niezwykle płodnych odpadach. Śmieci stają się paradoksalną, nową żyzną glebą w czasach, gdy człowiek zmienia Ziemię aż po najgłębsze warstwy geologiczne ${ }^{35}$.

\section{Uprawianie śmieci}

Jedną z kluczowych ról Instytutu jest obserwowanie życia porostów, roślin i grzybów na znalezionych śmieciach. Jak wskazuje sama artystka: „Organizmy te nie rozpoznają terminu «bezużyteczny», dlatego tworzą prosty i kompletny system oparty na równowadze między produkcją a redukcją"36. Tworzące się złożone ekosystemy wykraczają poza kulturowe rozumienie śmieci jako rzeczy, które symbolizują śmierć

34 T. Morton, Ecology without Nature..., s. 113.

35 Trzeba tutaj jednak podkreślić, że pomimo ich potencjalności śmieci nadal stanowią jeden z najpoważniejszych problemów środowiskowych. Dostrzeganie tworzonych przez nie nowych form życia nie powinno przysłonić palącego problemu zmniejszania ilości odpadów w ogóle.

36 Center for Living Things... 
i rozpad, a nie wzrastające życie. Działalność Instytutu można wręcz nazwać specyficznym uprawianiem śmieci. Obiekty są zbierane jako pojedyncze śmieci-rośliny albo śmieci z fragmentami ekosystemów, na których się rozwinęły. Na tej podstawie tworzone są informacje na temat poszczególnych hybryd wraz $\mathrm{z}$ tworzeniem nowej taksonomii dla tych nie-naturalnych zjawisk ${ }^{37}$. Rośliny-śmieci, które natomiast bardzo wrosły $\mathrm{w}$ dany habitat, są $\mathrm{w}$ nim pozostawiane, jednocześnie poddawane są nieustannej obserwacji i dokumentacji ${ }^{38}$. Następuje tutaj proces odwrotny - zamiast porzucenia i ukrycia śmieci są one obserwowane, badane, a człowiek troszczy się o nie jak o rzadkie, zagrożone gatunki. Powstające samoistnie i spontanicznie, pokazują, jak bardzo współczesne relacje pomiędzy środowiskiem a wytworami człowieka wymykają się dotychczasowym klasyfikacjom, które jasno oddzielają to, co wartościowe i warte ochrony, od zjawisk niepotrzebnych i szkodliwych. Śmieci zaczynają symbolizować procesy życiowe, to, co witalne, podlegające fluktuacjom i zmianom. Ujawniają też, że same wysypiska, ale również składowiska śmieci, są czymś życiodajnym:

(...) bakterie nieustannie metabolizują odrzucone przedmioty w nowe substancje, które z kolei przenikają do gleby i wód gruntowych, by zostać wchłonięte przez rośliny, drzewa, zwierzęta, grzyby, owady i atmosferę. Śmieciowe substancje tworzą nowe sieci geo-biologiczne: przemieszczają się pionowo i poziomo na wysypiskach i kontynuują swoją podróż, gdy przeciekają poza komórki składowisk śmieci ${ }^{39}$.

Wysypiska oraz składowiska śmieci stają się przestrzeniami współpracy pomiędzy bakteriami a wytworami ludzkiej produkcji, sił geologicznych. Tworzą nowe rodzaje substancji i zjawisk, które mają realny wpływ na ekosystemy, zdrowie i życie zarówno ludzi, jak i innych nie-ludzkich bytów. Tym samym ponownie przenikają do pilnie strzeżonych tkanek przestrzeni miejskiej, transformując ją i nieustannie zmieniając. Stają się nieodłączną częścią miasta, częścią, która stawia opór puryfikacyjnym regulacjom, obnażając ich nieszczelność i niefunkcjonalność.

Przestrzeń, w której kolekcjonowane są zbierane i badane okazy Instytutu dla zywych rzeczy, jest niezwykle istotna w kontekście transgresyjnego potencjału śmieci. Instytut ma swoje centrum badawcze w starej szklarni, która przynależy do Ogrodu Botanicznego Uniwersytetu im. Adama Mickiewicza w Poznaniu. Śmieci, które wymknęły się procesowi zarządzania odpadami miejskimi, znajdując się na dzikich wysypiskach, zostają włączone $\mathrm{w}$ granice nie-ludzkiej przestrzeni w mieście, jakim jest ogród botaniczny. Stają się usankcjonowaną częścią przestrzeni miejskiej. Obiekty te, w ramach logiki funkcjonowania ogrodu botanicznego, zaczynają produkować wiedzę naukową nie tylko na swój temat, ale również na temat relacji ludzko-środowiskowych. W ten sposób uzyskują kolejny poziom sprawczości odebra-

\section{Ibidem.}

38 Ibidem.

39 M.J. Hird, Knowing Waste: Towards an Inhuman Epistemology, „Social Epistemology” 2012, vol. 26, nr 3-4, s. 457. 
ny tym przedmiotom w momencie naznaczenia ich znakiem śmieciowości. Trzeba podkreślić, że zasadza się ona bardziej na relacji pomiędzy danymi obiektami, a nie jest ich immanentną cechą. Ten nowy rodzaj sprawczości podkreśla konieczność tworzenia horyzontalnych demokratycznych relacji pomiędzy ludźmi i nie-ludzkimi bytami. W takich specyficznych warunkach mogą ujawniać nowe potencje i możliwości zmiany. Jednocześnie w związku z tym, że opuszczona szklarnia jest w stanie pewnego zniszczenia, projekt Lelonek nie poddaje się prostym procesom estetyzacji eksponatów, prezentowanych w ogrodzie jako piękne obiekty ciekawostki. Przestrzeń zaniedbana i nieużywana staje się miejscem przechowywania roślin-śmieci znajdowanych na nielegalnych wysypiskach. Jednocześnie zarówno sama szklarnia, jak i obiekty zyskują podwójny status. Są wartościowe, jak inne rośliny wystawiane w ogrodach na pokaz, jednocześnie wymykają się prostej waloryzacji ze względu na specyfikę szklarni-w-ruinie oraz samej swoje charakterystyki, zasadzającej się na życiu powstającym na odpadzie.

\section{Czego nas uczą miejskie śmieci}

Jedną z przyczyn, dlaczego śmieci przestały być postrzegane jako ,znak życia w akcji"40, jest dominujące skojarzenie ze śmiercią i środowiskową destrukcją. Związane to jest z pojawieniem się w XVIII wieku masowych śmieci, których rosnąca liczba była spowodowana coraz większą urbanizacją. To wtedy, jak wskazuje Joshua Ozias Reno, wprowadzony został system eksternalizacji praktyk zarządzania odpadami aż stało się to osobną dziedziną, niezbędną do funkcjonowania przestrzeni miejskich $^{41}$. Połączenie śmieci z destrukcją środowiska naturalnego w dużej części związane było z nasilającą się separacją człowieka od natury wraz z coraz częściej postulowaną koniecznością zupełnej dominacji nad przyrodą. Instytut dla żywych rze$c z y$ (już w samej nazwie) podważa i zmienia tę dychotomię zjawisk wartościowych i tych, które są odrzucane. Praca Lelonek ujawnia napięcie pomiędzy rozumieniem pojęć dzikości i nieużytków. Dzikość, jak rezerwuar kapitału, stanowi współcześnie pewną abstrakcję czy, wręcz niemożliwą do spełnienia, fantazję. W przeciwieństwie do koncepcji dzikiej przyrody koncepcja nieużytku oferuje możliwość bardziej odpowiedzialnego zrozumienia naszego miejsca w środowisku, włączenia w niego również naszych materialnych wytworów. Zamiast ograniczać Naturę do obszarów pozbawionych ludzkiej obecności ziemia jałowa obejmuje ludzi jako część przyrody, która zakłada, że nasze akcje są wyłącznie jednymi z wielu w splątanej i nieskończonej siatce wzajemnych relacji. Obiekty w kolekcji Lelonek stanowią połączenie idei dzikości i nieużytku. Posiadają wielki potencjał zmiany naszego stosunku do środowiska. Doprowadzają również do pewnej przepuszczalności granic pomiędzy tym, co dopuszczane do świadomości, a tym, co z niej jest usuwane. Są żyznym połącze-

40 J.O. Reno, Toward a New Theory of Waste..., s. 15.

41 Ibidem. 
niem wstrętu i utopii, które kryje w sobie ogromny potencjał: „Jako przestrzeń oporu, wyzwań, a ostatecznie możliwości i zmian, pustkowie może stać się paradygmatem krajobrazu dla naszych niepewnych i niepokojących czasów"42. W tym krajobrazie dopuszczana jest obecność śmieci zarówno jako śladów ran, które człowiek zadaje środowisku, jak i jako podłoża do rozwoju nowych, hybrydowych ekosystemów. Instytut dla żywych rzeczy dokłada nową warstwę do dyskusji o śmieciach i ich roli w obecnych czasach. Projekt pokazuje, że nie możemy już dłużej odrzucać nieużytków, wysypisk i składowisk śmieci, ponieważ stają się one formą nowej dzikości. Tworzą świat bez dotychczas rozumianej Natury, opierający się na jej alternatywie, ale dający nadzieję na przetrwanie.

Pozostaje pytanie, czy wręcz nie powinniśmy zakochać się (w całej etyczności gestu pokochania nie-ludzkiego w jego sztuczności) w produkowanych odpadach, tak by dostrzec generowane przez nie potencje i nowe sieci relacji. Wykroczenie poza strach przed produkcją śmieci umożliwi zobaczenie nowych rozwiązań i radzenia sobie odpadami. Instytut dla żywych rzeczy jest zarówno historią zniszczenia, jak i pewną alternatywą dla przyszłości, w której pozwolimy rozwijać się monstrualnym ekologiom, tak by współtworzyły z nami demokratyczne, nie-hierarchiczne miejsca współżycia. Hybrydowe połączenia odbywają się między organicznymi odpadkami, nieorganicznymi obiektami a organizmami i mikroorganizmami żyjącymi na wysypiskach. Tworzy się tym samym nowa ontologia ludzkiego i nie-ludzkiego współistnienia. Uważam, że potencjał miasta przyszłości leży właśnie w uwidocznieniu swoich nieczystości i obserwacji ich możliwości, a nie dążeniu do coraz większej sterylności. Rośliny-śmieci z kolekcji Diany Lelonek tym samym traktuję jako nowe otwarcie (nie tylko dla miasta) pozwalające na uważne śledzenie procesów dziejących się na marginesach ludzkiego świata.

\section{Bibliografia}

Bauman Z., O przemijaniu trwania, w: K. Kulikowska, C. Obracht-Prondzyński (red.), Śmieć w kulturze, Wydawnictwo Naukowe Katedra, Gdańsk 2015, s. 35-47.

Bauman Z., Życie na przemiat, przeł. T. Kunz, Wydawnictwo Literackie, Kraków 2005.

Bennett J., Vibrant Matter: A Political Ecology of Things, Duke University Press, DurhamLondon 2010.

Center for Living Things, http://centerforlivingthings.com/ (dostęp: 7.11.2019).

Chomik-Krzykawska A., Między odrzuceniem a przyswojeniem. Odpad udomowiony, „Kultura Współczesna” 2007, nr 4 (54), s. 32-44.

Davis H., Life \& Death in the Anthropocene: A Short History of Plastic, w: H. Davis, E. Turpin (red.), Art in Anthropocene: Encounters among Aesthetics, Politics, Environments and Epistemologies, Open Humanities Press, London 2015, s. 347-358.

Davis H., Turpin E. (red.), Art in Anthropocene: Encounters among Aesthetics, Politics, Environments and Epistemologies, Open Humanities Press, London 2015.

42 V. Di Palma, Wasteland..., s. 244. 
Di Palma V., Wasteland: A History, Yale University Press, New Haven-London 2014.

Douglas M., Czystość i zmaza, przeł. M. Bucholc, Państwowy Instytut Wydawniczy, Warszawa 2007.

Galland A., Waste \& Opportunity: U.S. Beverage Container Recycling Scorecard and Report, As You Sow, San Francisco, CA 2008.

Kennedy G., An Ontology of Trash: The Disposable and Its Problematic Nature, State University of New York Press, New York 2007.

Krajewski M., Śmieć w sztuce. Sztuka jako śmieć, „Zeszyty Artystyczne” 2004, nr 13, s. 1-11.

Lelonek D., Center for Living Things, http://dianalelonek.com/portfolio/center-for-the-livingthings/ (dostęp: 7.11.2019).

Leociak J., Góry śmieci otulały wata smrodu wszystko, co żyło. (Śmieci w getcie warszawskim w perspektywie środowiskowej historii Zagłady), „Teksty Drugie” 2017, nr 2, s. 109-131.

Hird M.J., Knowing Waste: Towards an Inhuman Epistemology, „Social Epistemology” 2012, nr 26 (3-4), October, s. 453-469.

Morton T., Dark Ecology: For a Logic of Future Coexistence, Columbia University Press, New York 2016.

Morton T., Ecology without Nature: Rethinking Environmental Aesthetics, Harvard University Press, Cambridge, MA-London 2007.

Morton T., Hyperobjects: Philosophy and Ecology after the End of the World, University of Minnesota Press, Minneapolis-London 2013.

Morton T., Realist Magic: Objects, Ontology, Causality, Open Humanities Press, Ann Arbor 2013.

Możdżyński P., Prawdy odpadu. Najważniejsze konteksty i znaczenia zwiazane ze śmieciami w sztukach wizualnych i dizajnie XX $i$ XX wieku, w: K. Kulikowska, C. Obracht-Prondzyński (red.), Śmieć w kulturze, Wydawnictwo Naukowe Katedra, Gdańsk 2015, s. 421-444.

Pessel W., Antropologia nieczystości. Studia z kultury sanitarnej Warszawy, Wydawnictwo Trio, Warszawa 2010.

Reno J.O., Toward a New Theory of Waste: From 'Matter out of Place' to Signs of Life, „Theory, Culture \& Society" 2014, vol. 31 (6), s. 1-25. 